\title{
The Speaking Individual's Presupposition Base as a Reflection of the Picture of the World and the Linguistic Picture of the World
}

\author{
Hranush Tovmasyan \\ Yerevan Bryusov State University of Languages and Social Sciences
}

\begin{abstract}
The article is an attempt to shed light on one of the most interesting issues on the crossroads of psycholinguistics and pragmatics - the picture of the world and the linguistic picture of the world as a means of shaping the speaking individual's presupposition base, which allows him/her to communicate effectively in sociocultural ambient. The outcomes of the article allow to make the following statement: the presupposition base of the speaking individual is based on the linguistic picture of the world, which constitutes its linguistic component, as well as on the picture of the world, which constitutes its phenomenological component. The article also clarifies the differences between the notions of linguistic individual and speaking individual, consciousness and linguistic consciousness, picture of the world and linguistic picture of the world since they play a central role in the process of forming the presupposition base.
\end{abstract}

Key words: picture of the world, linguistic picture of the world, presupposition base, consciousness, speaking individual.

\section{Introduction}

In the present paper I dwell upon the fundamental difference between the picture of the world and the linguistic picture of the world. Hence, I shape the idea of the presupposition base of the speaking individual and his/her communicative competence from the perspective of this difference. The core focus of the present paper is the anthropological view of how the speaking individual actually communicates via his/her presupposition base.

\section{Anthropology as the Main Stream of Linguistic Studies}

The second half of the $20^{\text {th }}$ century is marked by a significant scientific interest in the human being, his/her inner world, consciousness and subconsciousness. Linguistic studies have made great progress in the fields of human physiology, psychology and mental activity. The anthropological approach to the humanities raised a great interest in the oriental philosophy, art, postmodern philosophy, stream of consciousness, freudism, etc. It actually marked the end of existential and structural theories and a "renaissance" 
of the human being and his/her worldview. All this has made the individual the key point of linguistic studies.

Nevertheless, it is noteworthy that the focus of this interest was not just the human (homo sapiens), but the individual who is endowed with consciousness and a complex inner world. The latter stipulated the development of anthropological approach in the humanities (and non-humanities) such as psycholinguistics, cognitive linguistics, ethnolinguistics, pragmatics, sociolinguistics, cultural studies, etc. It also served as an impetus for the development of the study of conceptosphere, the linguistic picture of the world and linguistic consciousness.

According to the psycholinguistic research data (Leontyev 1993; Zimnyaya 1993; Vezhbitskaya 1996; Zhinkin 1958, etc.), there is no difference between consciousness and linguistic consciousness since consciousness itself is a linguistic phenomenon by nature and it is impossible to view these two notions separately. So we can conclude that consciousness is initially a linguistic phenomenon.

Before initiating the present research on the picture of the world and the linguistic picture of the world, I find it timely to define the notion of the speaking individual, proceeding from the scientific data (Karaulov 1982; Johnstone 1996). It is noteworthy that initially the term "linguistic individual" appeared in linguistic literature before it was introduced into the sphere of scientific terminology by Yu. Karaulov (1982). This idea was further developed in the work of B. Johnstone (1996). Both scholars view the linguistic individual as a human being who is endowed with the potential of learning a language and who masters it in the process of his/her socialization. Hence, in my understanding the linguistic individual is in fact the language speaker.

\section{The Notion of Speaking Individual and His/Her Presupposition Base}

Thus, what is a speaking individual and how is it interpreted in linguistic studies. It should be mentioned that this subdivision comes from F. de Saussure's trilogy: language, linguistic competence and performance. The latter encompasses the former two (Saussure 1933). In other words, four components of language-speech are distinguished: language, linguistic competence, linguistic performance and speech. A. Leontyev offers almost the same subdivision: language as an object, language as process, and language as competence (Leontyev 1969:23). A. Leontyev's subdivision actually offers to distinguish between four aspects in the dichotomy language-speech: language as an object, language as process, language as competence and speech performance. The last component, speech performance, comes up as a result of the cooperative functioning of the former three. The notions of linguistic individual and speaking individual correspond to the first and third subdivision in F. de Saussure's and A. Leontyev's four-aspect formation. Besides, the notions of linguistic individual and speaking individual stand in paradigmatic relations: if the linguistic individual is the 
invariant, then the speaking individual is its variant. Hence, proceeding from the abovesaid, it can be assumed that the linguistic individual acts as a possibility of languagespeech dichotomy while the speaking individual is its realization or actualization. Besides, the speaking individual is a functional entity as he/she have to make an elaborate choice from the store of their linguistic knowledge and shape his/her speech, that is to say the text, so as to make it appropriate in the given communicative situation and serve the communicative intentions and communicative strategies. The above-said can be accomplished by Yu. Stepanov's words “According to contemporary linguistic thought the speech act together with its center - the speaker - is the core of the whole language system" (Stepanov 1975:139).

As has already been stated, according to research data, consciousness and linguistic consciousness are in fact identical. It should be mentioned that we cannot say the same about the picture of the world and the linguistic picture of the world since they are fundamentally diverse phenomena. The former is the reflection of the reality in our consciousness, that is to say, it discloses how a social being reflects the world surrounding him/her in his/her consciousness. It is noteworthy that the picture of the world is an abstract, mental phenomenon, while the linguistic picture of the world is a material entity embodied via language signs. It in fact reflects how the given language materializes the world: converts real-world phenomena into language units.

Hence, the aim of the present paper is to disclose the difference between the picture of the world and the linguistic picture of the world, proceeding from the mainstream studies of the field, as well as to show how the speaking individual shapes his/her presupposition base through both the linguistic and non-linguistic pictures of the world.

The presupposition base is the bulk of knowledge and ideas which are first reflected and then shaped as such in a human being's consciousness as a result of the cognitive, speculative process which starts at his/her birth and develops throughout his/her life.

According to A. Leontyev the notion "the picture of the world" should never be identified with the notions "the linguistic picture of the world" or "the cognitive picture of the world" (Leontyev 1993:18). Let us try to find out why. As M. Heidegger claims, "the essentially perceived picture of the world does not mean the picture portraying the world, but rather the world perceived as a picture" (Heidegger 1986:103). In other words, the picture of the world is the reality reflected in a human being's mind. Modern psycholinguistics considers the notions consciousness and the picture of the world/ model of the world to be close but not synonymic (see A. Leontyev, N. Ufimtseva et al.). It is noteworthy that the human being shapes the picture of the world in the process of his/her socialization and, consequently, that picture of the world cannot but carry the national-cultural imprint. T. Utrobina puts it that the picture of the world "is a sum of mental meanings, most general ideas about the world" (Utrobina1997:72). T. Tsivyan considers the picture of the world as processing information about human beings and their surroundings, as a shortened and simplified reflection of the above-mentioned sum 
of ideas (Tsivyan 1990:5). V. Kolshanskiy argues that the picture of the world reflected in a human's mind derives from the real world, existing objectively (Kolshanskiy 1990:15). The picture of the world appears to be an ideal, conceptual entity which has a twofold nature: the non-objectivized aspect as a unit of consciousness, will or vital activity, and the objectivized aspect - in the form of diverse traces of consciousness, will and vital activity, particularly in the form of signemic entities, texts (including art, architecture, social structures, language) (Postovalova 1987:66). At the same time the picture of the world, which is perceived as a "known integral system", is characterized by order and unity of the meanings and ideas forming it (Kubryakova 1986:141).

V. Kolshanskiy claims that the relationship between the real, objectively existing world, which is independent of human will and the ideal mental picture of the world reflected in human mind, is possible through a "secondary ideal world incorporated in linguistic body" (Kolshanskiy 1990:18), that is to say, through the linguistic picture of the world which appears "by way of deep stratum of the general picture of the world" (Postovalova 1987:66). In this respect Yu. Apresyan holds that any natural language reflects its special way of conceptualization (perception and organization) of the world, moreover the meanings reflected in the language shape a common system of views that shapes a "group philosophy" that "is obligated" upon all the speakers of the given language as mandatory (Apresyan 1995). V. Postolatova argues that "Language does not reflect the world but rather images it; displays and embodies the human being's conceptual picture of the world" (Postovalova1987:67).

Hence, V. Maslova states that "the linguistic picture of the world can be defined as a totality of knowledge about the world that is imprinted in vocabulary, phraseology and grammar" (Maslova 1997:49).

Proceeding from what has been said above it can be concluded that the linguistic picture of the world is an original material matrix in which the picture of the world is imprinted and actualized.

Thus, the linguistic picture of the world imprints "the world in the mirror of the language", while the picture of the world is "the reflection of the real world in human mind which is mediated through substantive meanings and respective cognitive schemata which can undergo conscious reflection" (Leontyev 1993:18), that is to say, as an outcome of the past of the nation to which we class ourselves (Ufimtseva 1996:161).

The research carried out in this field shows that behind outer resemblance of the formal structure of linguistic consciousness there can be absolutely diverse pictures of the world as, for example, in the case of the English and Russians (Ufimtseva 1996:160). On the other hand, the drastic difference between structures of diverse linguistic pictures of the world does not testify that the pictures of the world underlying them must be very diverse as well. For example, in the Armenian and English linguistic pictures of the world there are very few names of pasta. In Armenian there is only one native word denoting pasta шпһгчи. All other nominations of pasta existing in 
Armenian are either Italian borrowings or calques. According to Wikipedia Free Encyclopedia there are the following nominations denoting pasta types according to its form and size common in Armenian speech: vulupna, tingJnıphlatin nu thtunnıphl-

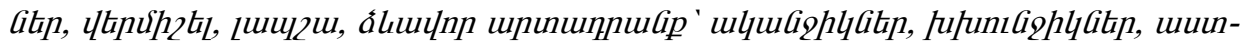
nhlakn, uшunh6hlakn, onulatin (<https://hy.wikipedia.org/wiki/\%D5\%84\%D5\%A1 $\%$ D5\%AF\%D5\%A1\%D6\%80\%D5\%B8\%D5\%B6\%D5\%A5\%D5\%B2\%D5\%A5\%D5 $\% \mathrm{~B} 6>$ ).

In English there are names of pasta, but actually they are not English nominations either but rather Italian borrowings. It means these words do not belong to the English picture of the world. Hence, from the point of view of the quantity of words nominating pasta the English and Armenian linguistic pictures of the world display a seeming resemblance. Yet, it does not presuppose resemblance of their respective pictures of the world.

Unlike the Armenian linguistic picture of the world, the Italian one abounds in names of pasta: ravioli, lasangne, tagliatelli, spaghetti, penne, linguine, conchiglie, fettucine, tacconi, spugnette, fiori di mare, creste, etc, though the pictures of the world of these two languages are not very different. Thus, the linguistic picture of the world reflects what there is actually in the world.

The linguistic pictures of the world of English, Armenian and Italian also display differences in their grammatical aspect, as for example the quantity and position of the definite article is very different in these languages. In Armenian the definite article is formally actualized through post-positional variants $\not / G$, in Italian its counterparts are represented by $l a / l e, i l / i$, lo/gli pre-positional variants. In English the definite article comes in pre-position and in speech it is actualized only via its phonetic variants [ðљ/ $\partial i$ ], depending on the fact whether the following word starts with a consonant or a vowel. In Armenian the definite article comes in post-position and its variation is conditioned by the letter the following word starts with (if the following word starts with a vowel then the definite article actualizes with its $-G$ variant, if it starts with a consonant there comes its $-\not p$ variant). In Italian it comes in pre-position and displays a twofold variation - gender- and number-conditioned. The latter is peculiar neither to English nor to Armenian. In addition, Italian has another peculiarity: besides gender and number distinction, there is a group of definite articles $(l o / g l i)$ that are used if the word they define starts with a vowel or $\mathrm{s}+$ consonant. Thus, the great variability of the Italian definite article is conditioned by the above-mentioned criteria: the la/le- feminine singular/ feminine plural, $i l / i$ - masculine singular/ masculine plural, lo/gli- vowel or $\mathrm{s}+$ consonant singular / vowel or $\mathrm{s}+$ consonant plural.

Consider the colour-scheme naming patterns in English, Armenian and Russian where, depending on the difference in the picture of the world, the languages display different sets of words naming the same colours. The English language has only the linguistic items blue, navy and azure which name different shades of blue. The first item 
has two variations: light blue/ sky blue and dark blue, though A. Hornby's "Oxford Student's Dictionary of Current English" also contains the collocation navy blue, meaning dark blue. The word azure is quite rare but for fiction. According to bararanonline.com (Armenian online dictionary), contrary to English, Armenian displays a rich variation of linguistic items designating different shades of blue, namely: quшпıыn, knlauqnıja,

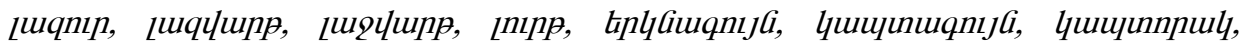

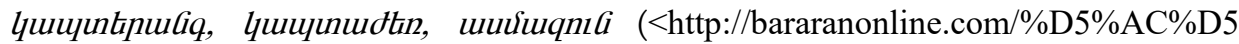
$\% \mathrm{~A} 1 \% \mathrm{D} 5 \% \mathrm{~A} 6 \% \mathrm{D} 5 \% \mathrm{~B} 8 \% \mathrm{D} 6 \% 82 \% \mathrm{D} 6 \% 80>$ ).

In Russian the colour in question is actualized via two independent nominative items: голубой and синий that allow of some word derivation such as светло-синий, темно-синий, светло-голубой, темно-голубой, еtс.

Another very vivid example of divergences of linguistic pictures of the world depending on the difference of the real picture of the world is displayed by the following example: in Lappish there are no words designating vehicles and their types, but there are almost 50 words nominating different types of snow. We observe the opposite phenomenon in English, Armenian, Russian, etc., where there are sets of words designating different types of vehicles and very few words nominating types of snow. For example, in English there is the following set of entities naming types of vehicles: car, sedan, hatchback, van, minivan, crossover, SUV, truck, lorry, bus, etc. and the following set for types of snow: snow, sleet, drift, slush, flurry, blizzard (Boas 1911; Whorf 1940). In Armenian we observe the following set some items of which are

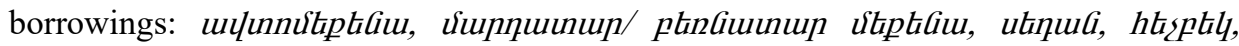

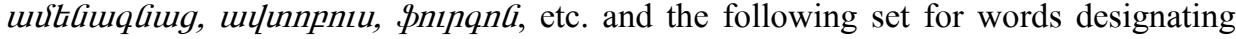
snow: ájnıl, ájnıGuunphl, vuapuquplnıun, áGupntp. Russian has the following set for vehicle types: легковая/ грузовая машина, автомобиль, седан, хэтчбэк, кроссовер, фургон, грузовик, автобус, etc. and снег, мокрый снег, in some way the word слякоть, for types of snow.

The analysis carried out above shows that the linguistic picture of the world and the presupposition base of a speaking individual are directly shaped under the influence of the reality he/she lives in.

On the other hand, there is also the opposite phenomenon when the linguistic picture of the world in its turn makes the comprehension of the actual division of the real world phenomena complicated, that is to say it complicates the comprehension of the real picture of the world. For example, those who have mastered languages with a complicated tense system find it hard not so much the choice of the forms but rather the actual division of the objective time axis. Such cases are the verbal aspect in Russian, the future in the past tense in English, etc.

It is noteworthy that the presupposition base of the speaking individual is composed of two basic aspects - the linguistic and the phenomenological. The grammatical aspect of the linguistic picture of the world forms the linguistic component of the 
presupposition base, while the lexical items of diverse meanings compose its phenomenological component.

\section{Conclusion}

Thus, the analysis testifies that the linguistic picture of the world and the presupposition base of the speaking individual have cognitive nature. The latter comes to prove that the linguistic picture of the world and the presupposition base of the speaking individual directly reflect the real world phenomena which in the language acquire linguistic forms (lexical, grammatical, phraseological). The linguistic forms in their turn create a text that carry in them the whole load of the speaking individual's presupposition base - cultural, national, social, psychological, etc.

\section{References:}

1. Apresyan, Yu. (1995) Obraz cheloveka po dannym yazyka: popytka sistemnogo opisaniya. // Voprosy yazykoznaniya. M.: Nauka, № 1.

2. Armenian Online Dictionary. Available at: $<$ http://bararanonline.com/\%D5\%AC $\%$ D5\%A1\%D5\%A6\%D5\%B8\%D6\%82\%D6\%80> [Accessed August 2015]

3. Boas, F. (1911) The Handbook of North American Indians. Vol. I, Washington, DC: Smithsonian Institution. Available at: <http://biblio.wdfiles.com/local--files/boas1911-introduction/boas_1911_introduction.pdf $>$ [Accessed August 2015]

4. Heidegger, M. (1986) Vremya kartiny mira. // Novaya tekhnokraticheskaya volna na zapade. M.: Progress.

5. Hornby, A. (1988) Oxford Student's Dictionary of Current English. 2nd Revised edition. Oxford: OUP.

6. Johnstone, B. (1996) The Linguistic Individual: Self-Expression in Language and Linguistics. Oxford: OUP. Available at: $<$ https://books.google.am/books $\times$ id=2oczx BLIrsgC\&pg=PA140\&lpg=PA140\&dq=SPEAKING+individual,+LINGUISTICS\& source $=$ bl\&ots $=$ oZW5Dp2BIW\&sig $=$ IJcWMRisHHrhvpHQNcMx7DE_j60\&hl=hy $\&$ sa $=$ X\&ved=0CFIQ6AEwB2oVChMI7PPVquqCxwIVwtssCh1AVwDr\#v=onepag e\&q=SPEAKING\%20individual\%2C\%20LINGUISTICS\&f=false $>\quad[$ Accessed August 2015]

7. Karaulov, Yu. (1982) Rol' pretsedentnykh tekstov $v$ strukture $i$ funktsionitovanii yazykovoy lichnosti. // VI Mezdunarodniy kongress MAPRYaL. Sovremennoe sostoyanie i osnovy problemy izucheniya i prepodavaniya russkogo yazyka i literatury. Doklady sovetskoy delegatsii. M.: Russkiy yazyk.

8. Kolshanskiy, G. (1990) Obyektivnaya kartina mira v poznanii i yazyke. M.: Nauka.

9. Kubryakova, E. (1986) Nominativnyi aspekt rechevoi deyatel'nosti. M.: Nauka.

10. Leontyev, A. (1969) Yazyk, rech, rechevaya deyatelnost'. İ.: Prosveshchcenie.

11. Leontyev, A. et al.; Leontyev, A.; Rokhlin, L.; Savitskaya, A.; Ufimtseva, N.; 
Shakhnarovich, A. (1972) Nekotorye problemy rechevoy patalogii pri shizofrenii. // Materialy IV Vsesoyuznogo simpoziuma po psikholingvistike i teorii kommunikatsii. M.: Nauka.

12. Leontyev, A. (1993) Yazykovoe soznanie i obraz mira. // Yazyk i soznanie: paradoksal'naya ratsional'nost'. M.: Institut yazykoznaniya RAN.

13. Maslova, V. (1997) Vvedenie v lingvokul'turologiyu. M.: Nasledie.

14. Postovalova, I. (1987) Sushchestvuet li yazykovaya kartina mira $\times$ // Yazyk kak kommunikativnaya deyatelnost' cheloveka. Sbornik nauch. trudov MGPIIYA. Vypusk. 284. M.

15. Saussure, F. de (1933) Kurs obshchey lingvistiki. M.: Sotsekgiz.

16. Stepanov, Yu. (1975) Osnovy obshchego yazykoznaniya. M.: Prosveshchenie.

17. Tsivyan, T. (1990) Lingvsticheskie osnovy balkanskoy modeli mira. M.: Nauka.

18. Ufimtseva, N. (1996) Russkie: opyt eshe odnogo samopoznaniya // Etnokul'turnaya spetsifika yazykovogo soznaniya. M.: Institut yazykoznaniya RAN.

19. Utrobina, T. (1997) Yazykovye sredstva reprezentatsii kontseptual'noy kartiny mira (na materiale satiricheskikh rasskazov M.M. Zoschenko 1920-kh godov). // Tekst: struktura i funktsionirovanie. Vypusk 2. Barnaul: KemGU.

20. Vezhbitskaya, A. (1996) Yazyk.Kul'tura. Poznanie. İ.: Russkie Slovari.

21. Whorf, B. (1940) /J. Caroll (Ed.) (1956) Language, Thought and Reality: selected writings of Benjamin Lee Whorf. Cambridge, MA: MIT Press.

22. Wikipedia Free Encyclopedia. Available at: $<$ https://hy.wikipedia.org/wiki/\%D5\% 84\%D5\%A1\%D5\%AF\%D5\%A1\%D6\%80\%D5\%B8\%D5\%B6\%D5\%A5\%D5\%B2 $\%$ D5\%A5\%D5\%B6> [Accessed September 2015]

23. Zhinkin, N. (1958) Mekhanizmy rechi. M.: Izdatel'stvo Akademii Pedagogicheskikh Nauk.

24.Zimnyaya, I. (1993) Sposob formirovaniya i formulirovaniya mysli kak realnost' yazykovogo soznaniya. // Yazyk i soznanie: paradoksal'naya ratsional'nost'. M.: IYA RAN.

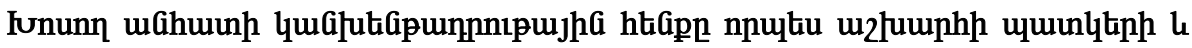

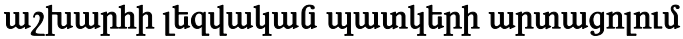

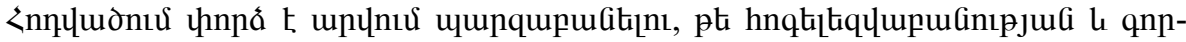

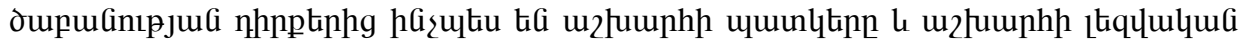

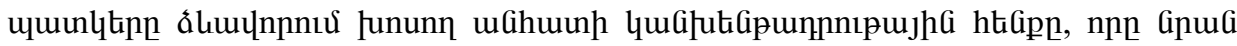

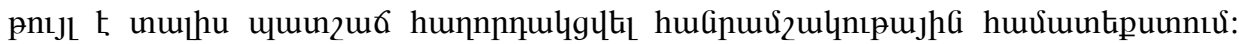

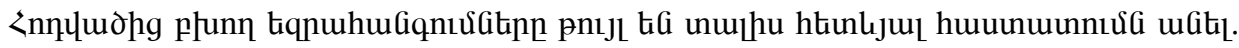

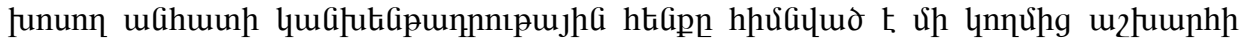

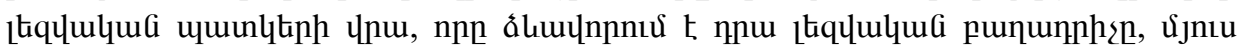

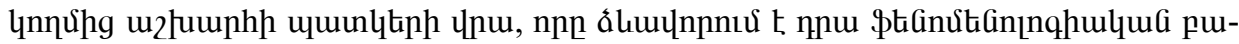




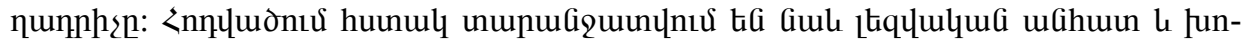

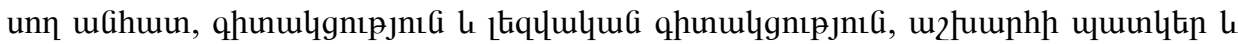

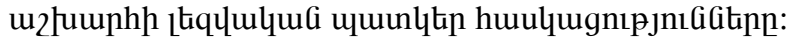

\section{Пресуппозиционная база говорящей личности как отражение картины мира и языковой картины мира}

В статье рассматривается одна из самых актуальных проблем на перекрестке психолингвистики и прагматики: картина мира и языковая картина мира как способ формирования пресуппозиционной базы говорящей личности, которая позволяет ему эффективно общаться в социокультурном пространстве. На основании результатов исследования можно утверждать, что пресуппозиционная база говорящей личности основана с одной стороны на языковой картине мира, которая формирует ее языковой аспект и картине мира, которая формирует ее феноменологический аспект. В статье также четко разграничиваются такие понятия, как языковая личность и говорящая личность, сознание и языковое сознание, картина мира и языковая картина мира, так как эти понятия играют центральную роль в процессе формирования пресуппозиционной базы. 